Sanctifying the Name of God 
JEWISH CULTURE AND CONTEXTS

Published in association with the Center for Advanced Judaic Studies of the University of Pennsylvania

David B. Ruderman, Series Editor

\author{
Advisory Board \\ Richard I. Cohen \\ Moshe Idel \\ Deborah Dash Moore \\ Ada Rapoport-Albert \\ David Stern
}

A complete list of books in the series is available from the publisher. 


\section{Sanctifying the Name of God}

Jewish Martyrs and Jewish Memories of the First Crusade

Jeremy Cohen

\section{$\overline{\text { PENN }}$}

University of Pennsylvania Press

Philadelphia 
Copyright (C) 2004 University of Pennsylvania Press

All rights reserved

Printed in the United States of America on acid-free paper

$\begin{array}{llllllllll}10 & 9 & 8 & 7 & 6 & 5 & 4 & 3 & 2 & 1\end{array}$

First paperback edition 2006

Published by

University of Pennsylvania Press

Philadelphia, Pennsylvania 19104-4112

Library of Congress Cataloging-in-Publication Data

Cohen, Jeremy, 1953-

Santifying the name of God: Jewish martyrs and Jewish memories of the First Crusade I Jeremy Cohen.

p. cm. -- (Jewish culture and contexts)

Includes bibliographical references and index.

ISBN-13: 978-o-8122-3780-1 (cloth : alk. paper)

ISBN-10: 0-8122-3780-3 (cloth: alk. paper)

ISBN-13: 978-0-8122-1956-2 (pbk. : alk. paper)

ISBN-10: o-8122-1956-2 (pbk. : alk. paper)

1. Jews-Germany-History-1096-1147. 2. Jews-Persecutions-Germany.

3. Crusades-First, 1096-1099. 4. Germany-Ethnic relations. I. Title. II. Series.

DS $135 . G_{31} \mathrm{C}_{4} \quad 2004$

$943^{\prime} .004924-d c 22$

2003069063 